\title{
Evaluating the Applicability of Phytoplankton Community Indices in Assessing The Ecological Quality Status (EcoQS) of a Coastal Ecosystem (Thane Creek, India): Mono-Metric vs Multi-Metric Approach
}

\section{Revati Hardikar}

National Institute of Oceanography CSIR

Haridevi Chanjaplackal Kesavan ( $\nabla$ haridevick75@gmail.com )

National Institute of Oceanography CSIR

\section{Shantaj Deshbhratar}

Bombay University: University of Mumbai

\section{Research Article}

Keywords: Phytoplankton community indices, Ecological quality status, Multi-metric phytoplankton index, Integrated phytoplankton index, Thane Creek, India

Posted Date: April 16th, 2021

DOI: https://doi.org/10.21203/rs.3.rs-298428/v1

License: (c) (i) This work is licensed under a Creative Commons Attribution 4.0 International License. Read Full License 


\section{Abstract}

The ecological quality status (EcoQS) of Thane Creek which is surrounded by a highly urbanized and industrialized sector of Mumbai was assessed by considering six phytoplankton community indices. Sampling was carried during Premonsoon to compare the efficiency of selected indices (Chl $a$, abundance, H', MDI, IPI and MMPI) in the tropical setting. Ecostatus proposed by selected phytoplankton indices assigned a 'moderate-good' status to phytoplankton zone (PZ)-I, 'moderate-poor' to PZ-II while 'bad' to PZ-III. Comparatively, MMPI appeared to be the most efficient water quality index because of its capability in discriminating between 'acceptable' and 'not-acceptable' EcoQS. The gradient of anthropic activities along the creek plays a major role in deciding the EcoQS of Thane Creek. Limitations of all indices in evaluating environmental quality were also discussed in the present study. The investigation could provide a fillip to policymakers who are undertaking coastal water quality improvement initiatives.

\section{Introduction}

Coastal ecosystems are well known for their biological richness worldwide and this is one of the main reasons behind the attraction of these areas for the establishment and development of the human population. The creeks and rivers of developing countries being treated as a sink for more than $70 \%$ of untreated industrial water and $90 \%$ of sewage waste (Creel 2003). This condition has exerted enormous pressure on coastal water bodies resulting in deterioration of water quality, reduction in biodiversity, adverse modification of critical habitats which overall hampers the ecosystem's health (Herrera-Silveira and Morales-Ojeda 2009). Such adverse impacts on the ecosystem have necessitated an immediate action that diagnoses the current status and categorizes the ecosystem under prevailing status. Understanding and quantifying the feedback of the biological community is necessary as the coastal ecosystem is severely under modification through anthropogenic intervention.

Among the biological elements, phytoplankton assemblages are the first that responds to the unfavorable impacts of eutrophication in the estuarine and coastal zone (Nixon 1995). Among the key biological elements, phytoplankton are the only planktonic elements considered in water framework directives (WFD). Phytoplankton undertakes an essential ecological function of primary production, being at the base of the energy pyramid they directly or indirectly fuel the entire food web (Domingues et al. 2008). Additionally, due to short generation time compared to other biological elements phytoplankton assemblage respond quickly to environmental changes related to water quality, hydrology or climate (Delvin et al. 2007; Domingues et al. 2008). Due to this characteristic feature, phytoplankton attributes are usually employed as an indicator for assessing the eutrophication status in coastal ecosystems.

Traditionally, chlorophyll concentration is often used as a simple and collective measure of phytoplankton community response to eutrophication. However, the adverse effects of nutrient enrichment are not restricted to chlorophyll alone but it can also hamper community composition, abundance as well as frequency and intensity of bloom. Modifications in any one of these attributes can alter the energy flow and quality of food that fuels the higher trophic levels (Winder et al. 2017). In terms, 
this can hamper the ecosystem processes such as primary production, nutrient recycling, fisheries, aquaculture and microbial processes (Houde and Rutherford 1993; Cloern et al. 2014). Therefore, the categorization of creek based on ecological quality has been undertaken by applying phytoplankton community indices. Classification encapsulates complex ecological information into a simpler form to expedite easy interpretation by stakeholders and policymakers.

It has been observed that all extensively used phytoplankton water quality indices were mostly developed and tested in a temperate region under the sponsorship programs of the European Union Water Framework Directive (WFD) (Revilla et al. 2009; Spatharis and Tsirtsis 2010; Lugoli et al. 2012; Ni Longphuirt et al. 2019). Conversely, except for the Shannon Wiener diversity index (Thillai et al. 2010; Hardikar et al. 2017), the applicability of other most relevant phytoplankton community indices in determining the ecological status from the Indian sub-continent is rare. Hence it is relevant to test the usefulness of some widely used phytoplankton community indices in assessing the ecological quality status (EcoQS) of the coastal water body of this geographical region.

The northwest coast of India is one of the most industrialized areas and encompasses highly polluted ecosystems along its long coastline (NIO 2009). Thane Creek is a profoundly deteriorated ecosystem due to its proximity to highly urbanized Mumbai city and Asia's one of the largest Thane-Belapur Industrial complex (Jha et al. 2001; Singare et al. 2013). The dumping of pollutants into the creek has become a main concern for regulatory authorities trying to formulate remedial effective measures for restoring coastal ecosystem ecology. Therefore, the specific objective of this investigation was to test the applicability of selected phytoplankton community indices for evaluating the EcoQS of Thane Creek. From the plethora of biotic indices available four mono-metric indices viz. phytoplankton biomass (chlorophyll a), abundance, Shannon Wiener diversity index $\left(\mathrm{H}^{\prime}\right)$, Menhinick diversity index and two multimetric indices viz. integrated phytoplankton index (IPI) and multi-metric phytoplankton index (MMPI) were selected based on their robustness, ease in applicability and sensitivity. The present investigation is the first comprehensive and comparative study undertaken to evaluate the current EcoQS of Thane Creek by using attributes of the phytoplankton guild. The outcomes of the present study will deliver the details of relevant phytoplankton attributes which can be incorporated by stakeholders or policymakers into water quality classification schemes.

\section{Materials And Method}

\subsection{Study area}

The present investigation was conducted in Thane Creek surrounded by Mumbai city, the second largest coastal city in the world and also India's premier port. Mumbai is a heavily polluted and industrialized island city situated on the west coast of India. This island is separated from the mainland by Thane Creek on the east. Thane Creek (latitude $19^{\circ} 00^{\prime} \mathrm{N}$ to $19^{\circ} 15^{\prime} \mathrm{N}$; longitude $72^{\circ} 55^{\prime} \mathrm{E}$ to $73^{\circ} 00^{\prime} \mathrm{E}$ ) is a funnel shaped water body that expands at its southern end and opens into the Arabian Sea. Towards the northern end, it tapers gradually and meets the River Ulhas through a narrow channel. The creek may be 
considered an estuary during the southwest monsoon period. During this period, salinity drops about four units due to land drainage and river runoffs while during the rest of the seasons salinity is maintained in harmony with the seawater incursion. The Thane Creek experiences semi-diurnal tides with a mean tidal range of $5 \mathrm{~m}$ in the mouth region which decreases towards upstream (Thomas et al. 2019). The creek is highly bioactive and yields about two to three thousand metric tonnes of fish catch per year (Shingare 2010). Thane Creek receives effluents from wastewater treatment facilities (WWTFs) located at Bhandup, Ghatkopar, Colaba and also from industrial discharge channels from Navi-Mumbai on the east bank of the creek. Excluding a few large scale units, various medium and small scale industries releases their untreated or partially treated waste through unlined surface drains/nallah into the creek. Moreover, Thane Creek also receives domestic sewage from the suburbs of Mumbai. The quantity of effluents discharged through WWTF, Colaba outfall and various drains/nallahs are given in Table 1. The Mumbai Port (MbPT) and Jawaharlal Nehru Port (JNPT) deal with approximately $>30$ million tonnes of goods annually, further adds up pollutants in the creek through oil leakage, spills and corrosion. Hence the creek is considered as heavily impacted by myriad anthropogenic activities that can affect the overall environmental quality.

\subsection{Sampling and analysis}

Scrutiny of published literature from Thane Creek demonstrates that adverse environmental settings like eutrophication peaked during premonsoon when there is little or no freshwater input (Vijay et al. 2015). Hence it is considered that the response of the phytoplankton community to unfavorable conditions would be more severe during this season. Sivadas et al. (2016) have recommended that sampling during the decisive phase (premonsoon along the Indian west coast) was most favorable for testing the efficacy of biotic indices in the tropics. Therefore the field sampling was conducted during the premonsoon season of April 2018 at 16 selected locations (Figure 1). For a brief understanding, the study area was divided into four zones, upper creek (UC, TC1-TC3), middle creek (MC, TC4-TC7), lower creek (LC, TC8TC12) and coastal zone (CS, TC13-TC15). The station name, geographical coordinates, depth and type of stressors are shown in Table 2.

Duplicate water samples $(500 \mathrm{ml})$ were collected from the surface and near bottom at each station using a $5 \mathrm{~L}$ capacity Niskin water sampler. Samples for physico-chemical parameters such as temperature, salinity, pH, dissolved oxygen (DO) and inorganic nutrients were collected in $500 \mathrm{ml}$ clean plastic bottles. Water temperature was measured by handheld standard mercury thermometer (BRANNAN Brand, U.K.) and $\mathrm{pH}$ with microprocessor controlled $\mathrm{pH}$ meter. DO was measured by Winklers and salinity by Mohr titration method, as recommended by Grasshoff (1983). Dissolved inorganic nutrients like nitrite $\left(\mathrm{NO}_{2}\right)$, nitrate $\left(\mathrm{NO}_{3}\right)$, ammonia $\left(\mathrm{NH}_{4}\right)$, phosphate $\left(\mathrm{PO}_{4}\right)$ and silicate $\left(\mathrm{SiO}_{4}\right)$ were filtered through millipore filter paper $(0.45 \mu \mathrm{m})$ and analyzed by spectrophotometric procedure within $6 \mathrm{~h}$ of the collection as described by Grasshoff (1983).

Phytoplankton biomass (chlorophyll a) samples $(500 \mathrm{ml}$ ) were filled in amber color plastic bottles and kept in an icebox immediately after collection. In the laboratory, samples were filtered through GF/F filter paper (pore size $0.7 \mu \mathrm{m}, 47 \mathrm{~mm}$ diameter) under minimal pressure. Chlorophyll a pigment was extracted 
by keeping the filter paper in $90 \%$ acetone at $4^{\circ} \mathrm{C}$ for minimum of $18-20 \mathrm{hrs}$ and measured using a fluorometer (Turner trilogy, model 7200) following the standard protocol of Parsons et al. (1984). To enumerate the phytoplankton density and community structure, $500 \mathrm{ml}$ of sample was collected and fixed with $1 \%$ acidic lugol's solution. In the laboratory samples were kept undisturbed and after settling concentrated to $10 \mathrm{ml}$. An aliquot of $1 \mathrm{ml}$ from each concentrate was taken on the Sedgewick rafter chamber and counted in duplicate under an inverted microscope at 400X magnification. Phytoplankton identification was done to the lowest possible taxonomic level following the standard taxonomic keys of Subrahmanyan (1946); Desikachary et al. (1987); Tomas (1997) and their total abundance was expressed as cells $\mathrm{I}^{-1}$.

\subsection{Assessment of stress level using phytoplankton community based indices}

During the current study, six indices were employed at all stations to evaluate the ecostatus based on phytoplankton community attributes viz. chlorophyll $a$, abundance, Shannon Wiener diversity index ( $\left.\mathrm{H}^{\prime}\right)$, Menhinick diversity index (MDI), integrated phytoplankton index (IPI) and multi-metric phytoplankton index (MMPI). EcoQS of the study area was then assessed using a five-point scale viz high, good, moderate, poor and bad based on indices mentioned above. For the abundance index, a three-point scale was adopted.

The average value of chlorophyll a ( $\mathrm{Chl}$ a) was used to determine EcoQS of each station. The threshold values of $\mathrm{Chl}$ a described by Borja et al. 2004 were utilized to categorize stations under different classes. Abundance can be treated as a proxy for ecological disturbances, as the community growth is correlated with the nutrients enrichment. The stations were classified under different ecological classes based upon a scale proposed by Herrera-Silveira and Morales-Ojeda 2009. Shannon's index ( $\mathrm{H}^{\prime} \mathrm{log} 2$; Shannon and Wiener 1949) was calculated using the PRIMER V6 software. Evenness (E2) was estimated according to the formula described by Sheldon (1969) and Menhinick diversity index by Menhinick (1964).

To characterize water quality based on phytoplankton biomass, abundance and diversity, the IPI is implemented by considering the above mentioned attributes as described by Spatharis and Tsirtsis 2010 . The diversity in this case is expressed in terms of the Menhinick index. The MMPI encompasses all the structural components of the phytoplankton community that includes $\mathrm{Chl} a$, abundance, diversity and evenness. MMPI is calculated based on the formula developed by Ni Longphuirt et al. (2019) for a single water body being sampled. The thresholds adopted to classify each index under the five level scale with the reference used are given in Table 3. Reference conditions are a prerequisite to derive IPI and MMPI index values. An area with the least anthropogenic disturbances can be treated as a reference condition (Vincent et al. 2002). Therefore during the present investigation, the offshore location (TC16) was treated as a reference condition, i.e least impacted by anthropogenic activities due to its distance from major pollution sources on land $(20 \mathrm{~km})$ following Revilla et al. 2009.

The five ecological quality ( $\mathrm{EcoQ}$ ) classes were then divided into two categories 'acceptable' and 'not acceptable' to establish the level of agreement between six selected indices. The EcoQ class 'high' and 
'good' corresponds to acceptable status and scored as 1, while the EcoQ class such as 'moderate', 'poor' and 'bad' were included in not acceptable status and assigned 0 scores. The score allocated by each of the indices were summed for each station (range: 0-6). Finally, this summed score was used to determine the level of agreement (full/partial) and disagreement between indices as mentioned earlier (Blanchet et al. 2008).

\subsection{Data analysis}

The phytoplankton indices data were analyzed at significance $\leq 0.05$ for Spearman's Rank correlation to assess the relationship amongst all six indices. Before performing correlation, abundance and $\mathrm{Chl} a$ values were normalized with $\log _{10}$ transformation. The Bray-Curtis similarity coefficient was used to construct a similarity matrix based on $\log (X+1)$ transformed phytoplankton indices data. Subsequently, the similarity matrix was processed to non-metric multidimensional scaling (nMDS) ordination to visualize the grouping of stations based on similarities in indices values. All statistical analysis was performed using PRIMER v6.

\section{Results}

\section{Environmental variables and Phytoplankton assemblages}

The depth averaged values of physico-chemical parameters in Thane Creek were depicted in Table 7. The environmental variables such as temperature, salinity and $\mathrm{pH}$ did not show considerable variation throughout the study and ranged from $28.8-32.3^{\circ} \mathrm{C}$ (av. 30.77 $\pm 97^{\circ} \mathrm{C}$ ), 33.1-35.7 (av. 35.0 \pm 0.75$), 7.74-8.11$ (av. $7.9 \pm 0.10$ ) respectively. Comparatively low DO concentration was noticed in the upper creek (av. $3.59 \pm 0.57 \mathrm{mg} \mathrm{l}^{-1}$ ) while at the rest of the station it ranged between 5 and $6 \mathrm{mg} \mathrm{l}^{\mathrm{I}^{-1}}$. The concentration of DIN, phosphate and silicate in Thane Creek ranged from 5.72-40.40 $\mu \mathrm{M} \mathrm{l}^{-1}\left(\mathrm{av} .17 .14 \pm 11.06 \mu \mathrm{M} \mathrm{l}^{-1}\right), 0.48-$ $6.90 \mu \mathrm{M} \mathrm{l}^{-1}$ (av. 3.18 $\pm 2.41 \mu \mathrm{M} \mathrm{l}^{-1}$ ) and 11.71-30.14 $\mathrm{M} \mathrm{I}^{-1}$ (av. 12.98 $\pm 8.84 \mu \mathrm{M} \mathrm{I}^{-1}$ ) respectively. Dissolved inorganic nutrients showed a gradual decrease from the upper creek towards the coastal zone which might be due to the uptake by phytoplankton and dilution with coastal waters.

Altogether 86 phytoplankton species belonging to five classes such as diatoms (53 spp.), dinoflagellates (29 spp.), chlorophytes (01 sp.), cryptophytes (02 spp.) and euglenophytes (01 sp.) were identified in the present study. The phytoplankton community structure in the upper creek and coastal zone was predominantly contributed by diatoms, dinoflagellates and chlorophytes whereas the entire middle and lower creek zone was dominated only by diatoms. The study revealed an elevated count of phytoplankton species $\left(>10^{5}\right.$ cells $\left.^{l^{-1}}\right)$ such as Skeletonema costatum, Gunardia delicatula, Chaetoceros spp.

Thalassiosira spp., Pseudo-nitzschia spp. and Asterionellopsis sp. was observed in middle and lower creek zone. While in upper creek and coastal zone the total density was more or less equally distributed among all species.

\subsection{Assessment of ecological quality status}


The EcoQS and index value of each station by six phytoplankton community indices are mentioned in Table 4 and Figure 2. Chl an index ranged from 1.40 to $16.78 \mathrm{\mu g} \mathrm{I}^{-1}$ in the study region. Zone wise, the lowest Chl a value was observed at the coastal station (TC14) and the highest at the lower creek (TC9). The EcoQS derived by Chl an index as per the thresholds mentioned in Table 3 indicated that the upper, middle and lower creek fell predominantly in the 'moderate' category while coastal stations under the 'good' to 'high' category. Two stations (TC3 and TC8) qualified under 'poor' status while the only station tagged with 'bad' status was TC9 of the lower creek zone. Phytoplankton abundance as an index of EcoQS assessment ranged from $1.51 \times 10^{5}$ to $68.65 \times 10^{5} \mathrm{cells}^{-1}$ and the ecological status varied between 'moderate' to 'poor'. Following the defined thresholds (Table 3 ) upper creek and coastal stations were classified predominantly under the 'moderate' category. Towards the middle to lower creek zone, the EcoQS worsens to the 'poor' category.

Shannon Wiener diversity index $\left(\mathrm{H}^{\prime}\right)$ ranged from 0.93 to 3.70. The lowest diversity value was observed at lower creek classifying this zone under 'moderate' (TC8, TC9 and TC12) and 'bad' (TC10 and TC11) category while middle creek reflected 'moderate' EcoQS. The upper creek reflected 'good' status while the coastal stations demonstrated 'good' to TC13 and 'moderate' status to TC14, TC15. MDI values ranged from 0.02 to 0.07 with upper and coastal zone displayed 'moderate' EcoQS. The middle and lower creek displayed 'poor' and 'bad' status respectively except at TC4 (Moderate) and TC12 (Poor).

Out of 16 stations sampled, IPI index (min-max 0.0-0.90) assigned 'poor' status to 10 stations and 'bad' to1 location showing heavily disturbed ecological quality in the major stretch of the creek. In contrast, stations TC1 and TC13 were categorized under 'good' while TC14 and TC15 under 'moderate' ecological status. MMPI which integrates $\mathrm{Chl} a$, abundance, evenness and diversity to assess the EcoQS of the creek, ranged from 0.04 (TC9) to 0.76 (TC13). The derived MMPI values reflect 'moderate' to 'poor' status to the upper creek and 'poor' to 'bad' status to the middle and lower creek. The coastal zone displayed EcoQS in the range of 'moderate' to 'good' where, TC13 exhibited 'good', while TC14 and TC15 showed 'moderate' status. The offshore location (TC16) was assigned with 'good-high' EcoQS by six phytoplankton indices (Figure 2).

\subsection{Comparison between indices}

The ecostatus of each location based on six phytoplankton community indices was not always consistent and is shown in Figure 2. Chl $a$ index classified $80 \%$ stations as 'not acceptable' and $20 \%$ stations under 'acceptable' EcoQS. The more severe categorization was done by abundance and MDI index where $100 \%$ of stations were tagged with 'not acceptable' status. H' and MMPI index recorded $26.67 \%$ stations with 'acceptable' and $73.33 \%$ stations with 'not acceptable' status. Whereas, IPI index documented $13.33 \%$ and $86.66 \%$ stations under' acceptable' and 'not acceptable' respectively (Figure 3 ). It was observed that only $\mathrm{Chl}$ a index classify stations in all five classes while MMPI and IPI under four categories. Abundance and MDI index did not assign 'high' and 'good' ecological status to any of the stations. 
According to the sum of score method of Blanchet et al. 2008 (Table 5), 60\% of stations (middle to lower creek zone) displayed full agreement on 'not acceptable' status. Partial agreement on 'not acceptable' status (5 out of 6 indices agreed on 'acceptable' or 'not acceptable' status) occurred in $13.33 \%$ of stations (TC3, TC15) while $26.66 \%$ of stations (TC1-TC2, TC13-TC14) disagreed on status derived by six indices. Spearman Rank correlation between all indices exhibited a significant statistical correlation with each other (Table 6). MDI, H', IPI and MMPI were positively correlated with each other and negatively with abundance. Chl a was negatively correlated with IPI and MMPI while the correlation between Chl $a$ index and abundance, $\mathrm{H}^{\prime}$ and MDI were insignificant.

\subsection{Zone formation based on selected indices}

Three phytoplankton zones (PZ) were identified based on selected phytoplankton community indices (Figure 4). These zones partially overlapped with the zones formed based on the morphology of the creek (upper, middle, lower and coastal zones). Based on the phytoplankton community indices, phytoplankton zone I (PZ-I) includes stations TC1-TC2, TC13-TC15 which were predominantly characterized as 'moderate' to 'good' ecological condition. In this zone $56.67 \%$ indices accepted on 'moderate', $33.33 \%$ on 'good' and $6.67 \%$ on 'high' ecological status. The PZ-II comprised of stations TC3-TC7 and TC12 which displayed mostly 'poor' (58.33\%), 'moderate' (33.33\%) and 'bad' (5.56\%) ecological status. The PZ-III (TC8-TC11) was categorized mostly under 'bad' (50\%) and 'poor' (33.33\%) status. Overall it can be stated that the upper creek and coastal area displayed 'moderate' to 'good' while the middle and lower creek zone displayed poor to bad ecological quality status.

\section{Discussion}

Different zones of the Thane Creek were affected to a varying degree by numerous stressors as discussed in Table 1. In the present investigation, a five-point classification system was adopted to assess the EcoQS using phytoplankton community descriptors except for the abundance index. Phytoplankton indices incorporated biomass, abundance, diversity and evenness which are considered as indicators of an ecosystem's health condition. High phytoplankton abundance can decrease the amount and quality of light reaching the water column. Likewise, evenness and diversity can be useful descriptors of change in coastal hydrodynamics and water quality pattern (Herrera-Silveira and Morales-Ojeda 2009).

\subsection{EcoQS assessment of phytoplankton zone}

The community attributes of an efficient EcoQS assessment include the ease of measurements along with sensitivity in the determination of environmental status and also it should convey relevant information to decision makers for efficient management initiatives (Borja and Dauer 2008). In the current observations $\mathrm{Chl}$ a, abundance, $\mathrm{H}^{\prime}, \mathrm{MDI}, \mathrm{IPI}$ and MMPI were compared to evaluate their efficiency in establishing the EcoQS of the Thane Creek. Based on the anthropogenic activities mentioned in Table 2 through expert judgment and indices measured, it was inferred that the PZ-I was less impacted; PZ-II was heavily impacted whereas PZ-III was severely impacted. 
The PZ-I zone comprised of stations TC1 and TC2 in the upper creek and TC13 to TC15 in the mouth of Thane Creek. The upper creek area did not receive direct waste matter from major discharge points but to an extent domestic and sewage discharges entered through drains (non-point sources) on either side of the creek. Due to the shallow depth and limited exchange with seawater, the pollutant gets accumulated in this area exerting pressure on the phytoplankton community structure. As a result, the phytoplankton community indices assigned chiefly 'moderate' EcoQS to the above said zone. On the other hand stations at the mouth of the Thane Creek (TC13-TC15) received minimum anthropogenic pressure. Naidu and Sharma 2001 characterized this area with comparatively strong currents and a highly mixed water column. Even though it received minor disturbances through anthropogenic activities such as transportation, recreational and harbor related dredging, the pollutants got dispersed and diluted with the ebb and flood currents. The dilution of water helps in maintaining the water quality of this zone and assigned 'moderate' to 'good' EcoQS. The current observations were in agreement with the previous study conducted by Vijay et al. 2014; Vijay et al. 2015 and Thomas et al. 2019 who also observed that the tidal amplitude reduces towards the upper creek which led to the accumulation of pollutants while towards the lower stretch of the creek, availability of tidal water for dilution helps in improving the water quality.

The stations of PZ-II and PZ-III received a large amount of wastes from Asia's biggest Thane-Belapur industrial complex through Panvel Creek, Dharamtar Creek, Colaba outfall and also from few drains openings into the creek. Along with industrial and domestic waste, these zones were also affected by shipping related dredging, harbor, fishing and recreational activities. India's two premier ports JNPT and $\mathrm{MbPT}$ are also located in this area. The anthropogenic disturbance caused due to these activities exerted a detrimental effect on phytoplankton community structure classifying PZ-II and PZ-III under 'poor' to 'bad' EcoQS. Moreover, the study conducted by Sasamal et al. 2007 in Thane Creek also demonstrated the high load of industrial and domestic water in the middle and lower creek zone.

There was no site in the entire stretch of the creek which was completely free from anthropogenic interference. In general, it can be stated that the gradient of anthropic activities along the creek plays a major role in deciding the EcoQS of Thane Creek.

\subsection{Checking for efficiency: Mono-metric vs multi-metric approach}

Phytoplankton biomass ( $\mathrm{Chl} a$ ) is considered an excellent trophic state indicator. There is also a good consistency among phytoplankton biomass, primary production and eutrophication (Boyer et al. 2009). In the present study, $\mathrm{Chl} a$ index overestimated the ecological status. It categorized the entire creek mostly under 'moderate' to 'high' status despite single-species dominance of opportunistic species at locations TC4-TC6 (Guinardia delicatula) and TC6, TC7, TC10, TC11, TC12, TC14, TC15 (Skeletonema costatum). Moser Gao et al. 2012 also categorized these species as opportunistic mixers from an urbanized estuarine complex and its elevated count of $10^{6}$ cells I $^{-1}$ (Revilla et al. 2009) or 250000 cells l$^{-1}$ (Ni Longphuirt et al. 2019) was considered as a bloom that can affect the ecosystem health. The possible reasons for overestimation of status could be the considerable variability in cellular $\mathrm{Chl} a$ content (0.1$9.7 \%$ of fresh weight) depending on species (Boyer et al. 2009); secondly, even though Chl $a$ is 
photosynthetic pigment and found in all phytoplankton cells it only symbolize a portion of total biomass. The biomass of heterotrophic species is not considered in Chl a estimations (Domingues et al. 2008). These conditions explained the disparity in EcoQS assessment using $\mathrm{Chl} a$ and abundance index. $\mathrm{Ni}$ Longphuirt et al. 2019 also observed the discrepancy in Chl $a$ and abundance due to size differences in different cells. Therefore the EcoQS derived based on only $\mathrm{Chl} a$ index is considered inappropriate. The highest values of $\mathrm{Chl}$ a at station TC3, TC8 and TC9 were probably due to the influence of waste coming from Panvel and Dharamtar Creek. These stations were located near the mouth of Panvel and Dharamtar Creek, which receives a direct influence of domestic and industrial waste. The study was in agreement with the findings of Revilla et al. 2009 made in Basque coast, Spain, where the maximum Chl a value was observed at the station located near the estuarine mouth.

Phytoplankton abundance can be treated as a proxy for ecological disturbances since their growth rate is directly correlated with nutrient inputs. Due to the aforesaid weaknesses of $\mathrm{Chl} a$ index, the categorization of ecological status based on phytoplankton abundance appeared to be more conservative when weighted against $\mathrm{Chl} a$ index. The usefulness of the abundance index as a suitable bio-indicator was also endorsed by many researchers for estuarine and coastal water (Delvin et al. 2007; Revilla et al. 2009; Herrera-Silveira and Morales-Ojeda 2009; Spatharis and Tsirtsis 2010). During the present investigation, only 3 levels of classification was adopted for the abundance index. The abundance well differentiated the zones into the 'moderate' and 'poor' category according to the intensity of disturbances each station received (Table 2).

Shannon Wiener $\left(\mathrm{H}^{\prime}\right)$ and Menhinick (MDI) were two diversity indices tested in the present study for their suitability in the ecological status assessment. $\mathrm{H}^{\prime}$ has been an extensively used measure of diversity in community ecology (Digby and Kempton 1987; Heumann, Hackett \& Monfils 2015). In the present investigation, $\mathrm{H}^{\prime}$ overestimated ecological status, except at stations TC10, TC11 and TC14. Besides, $\mathrm{H}^{\prime}$ has given almost the same diversity values and thereby the same ecological status (moderate) to the majority of stations (TC4-TC9, TC12, TC14 and TC15), even though there was a wide range of variation in species richness (27-49 nos.) and total abundance (239500-6864900 cells $\mathrm{I}^{-1}$ ). Moreover, in the present study, $\mathrm{H}^{\prime}$ was found to be inefficient in differentiating between stations with species-poor phytoplankton assemblage with no dominance and species-rich assemblage with the dominance of one or a few species. The current observation was in accordance with the findings of Spatharis et al. 2011, from the coastal area of the Aegean Sea, Greece. Consequently during the present investigation, it was concluded that the Shannon diversity index $\left(\mathrm{H}^{\prime}\right)$ on phytoplankton assemblage was not suitable for water quality assessment (Spatharis and Tsirtsis 2010; Spatharis et al. 2011). This index was also criticized by many researchers saying its response mainly depends on species richness rather than the relative abundance of each species (Boyle et al. 1990; Karydis and Tsirtsis 1996; Simboura et al. 2005).

On the other hand, the Menhinick diversity index (MDI) exhibits linear and monotonic behavior with eutrophication (Spatharis and Tsirtsis 2010). It also well discriminates the stations between 'moderate', 'poor' and 'bad category. Its measurement is a function of total abundance and species richness; both these attributes are efficient in characterizing the EcoQS (Karydis and Tsirtsis 1996). Additionally, MDI 
also exhibited a stronger relationship than $\mathrm{H}^{\prime}$ with all other indices studied (Table 6). Thus in comparison with $\mathrm{H}^{\prime}, \mathrm{MDI}$ was found to be more efficient as a diagnostic tool in EcoQS assessment. This observation was consistent with the previous studies that investigated the suitability of MDI in ecological status assessment (Karydis and Tsirtsis 1996; Spatharis and Tsirtsis 2010; Spatharis et al. 2011; NincevicGladan et al. 2015; Ni Longphuirt et al. 2019).

With the ongoing discussion, it was concluded that although there is inconsistency, each index carries its own information. Therefore, the use of multi-metric indices combining various attributes into a single index is more appropriate in water quality assessment. Multi-metric indices are widely employed in the ecological assessment of water bodies due to their robustness than the component metrics (Lacouture et al. 2006; Wu et al. 2011). Moreover, multi-metric indices synthesize information from more than one ecological quality element, thereby reducing the possibility of error and also misleading of results. For that reason, during the present investigation, IPI and MMPI were the two multi-metric indices used to assess the ecological quality status of the creek. In the present observation, IPI assigned 'poor' EcoQS to majority of the stations even though with a wide range of IPI values (0.05-0.49). This suggested a low discriminating power between the 'poor' and 'bad' category. Due to this inconsistency, both indices explained only $26.66 \%$ agreement on status allocated to each station. On the other hand, MMPI gives equal weight to all quality classes and during the present investigation well discriminated stations in the 'good', 'moderate', 'poor' and 'bad' category. With these results, MMPI can be considered as more efficient in assessing EcoQS.

Furthermore, the intrinsic ability to differentiate between acceptable and not acceptable EcoQS is critical in selecting the suitable biotic indices. According to the classification given by Blanchet et al. 2008, Chl $a$, H', IPI and MMPI possess the substantial capacity to differentiate between 'acceptable' and 'not acceptable' EcoQS. Whereas, other indices agreed that the entire stretch of the creek had not acceptable status (Table 6). Chl a index assigned an acceptable status to the entire coastal zone, H' to the TC1-TC3 (upper creek) and TC13 (coastal zone) whereas the IPI and MMPI index to stations TC13. Since stations of the upper creek as well as TC14 and TC15 received anthropogenic disturbances, station TC13 was the only stations with minimum anthropogenic activities (Table 2). Consequently EcoQS assigned by IPI and MMPI was found to be more appropriate. Furthermore, considering the above mentioned limitations of $\mathrm{Chl} a, \mathrm{H}^{\prime}$ and IPI while the usefulness of multi-metric indices, MMPI was regarded as more sensitive for EcoQS assessment.

During the present study, regardless of the significant correlation between indices (Table 6), there were inconsistencies in EcoQS produced by each phytoplankton index. The observed correlation between indices was anticipated since the phytoplankton attributes used to calculate the index values were correlated with each other. An inconsistency that arises in ecological quality assessment by these indices can be due to the different methods and threshold values adopted by each index to calculate the index values. However, the classification must be based on a robust tool and it should able to synthesize information from more than one quality element. Therefore with the present investigation, the use of 
mono-metric indices on phytoplankton assemblage is not found to be appropriate for water quality assessment. In contrast, a multi-metric index (MMPI) was found more suitable for this purpose.

\section{Conclusion}

The present investigation was the first venture to study the efficiency of various attributes of the phytoplankton guild in evaluating EcoQS of Thane Creek. The Chl $a$ and 'H' index derived the most optimistic quality status but due to the functional limitation, the EcoQS exclusively based on these indices was appeared inappropriate. On the other hand, the multi-metric index-MMPI encompassed all the structural attributes of phytoplankton assemblages and appeared most effective in assessing ecostatus. This reinforced the idea that instead of a single element, all features of phytoplankton assemblage should also be considered when studying the impact of anthropogenic forcing. The present investigation could also be a model for researchers to perform a similar kind of work in coastal ecosystems along the Indian coast. However, further study may be required incorporating bloom intensity, species richness as well as density of harmful species in evaluating ecological quality status from the tropical region. Since there is no historical data available to represent reference condition, further studies including long term monitoring of water quality from less impacted sites along tropical coastal environments need to be initiated.

\section{Declarations}

\section{Acknowledgment}

The authors are grateful to Dr. Sunil Kumar Singh, Director, CSIR-National Institute of oceanography and Dr. Mohandas C., Scientist-in-Charge CSIR-NIO, Mumbai for facilitating the study. We also acknowledge Mr. Jubin Thomas for plotting sampling locations. We also express our sincere gratitude to $\mathrm{Dr}$. AnirudhRam and Dr. Rakesh P.S for their immense support to carry out the sampling.

\section{Ethics approval and consent to participate}

Not applicable

\section{Consent for publication}

Not applicable

\section{Availability of data and materials}

The datasets used and/or analysed during the current study are available from the corresponding author on reasonable request.

\section{Competing interests}


The authors declare that they have no competing interests.

\section{Funding}

Financial support from OLP 1708 and MLP 1802 (Council for Scientific and Industrial research, Govt. India) is gratefully acknowledged.

\section{Authors' contributions}

$\mathrm{RH}$ - Conceptualization, formal analysis and drafting of the manuscript. HCK-Involved in investigation, data curation and validation of research output. SD- Involved in review and editing of the manuscript.

\section{References}

1. Blanchet $H$, Lavesque N, Ruellet T, Dauvin JC, Sauriau PG, Desroy N, ... Bessineton C (2008) Use of biotic indices in semi-enclosed coastal ecosystems and transitional waters habitats-implications for the implementation of the European Water Framework Directive. Ecological indicators 8(4):360-372

2. Borja A, Dauer DM (2008) Assessing the environmental quality status in estuarine and coastal systems: comparing methodologies and indices. Ecological indicators 8(4):331-337

3. Borja Á, Dauer DM, Grémare A (2012) The importance of setting targets and reference conditions in assessing marine ecosystem quality. Ecol Ind 12(1):1-7

4. Borja Á, Franco J, Valencia V, Bald J, Muxika I, Belzunce MJ, Solaun O (2004) Implementation of the European water framework directive from the Basque country (northern Spain): a methodological approach. Mar Pollut Bull 48(3-4):209-218

5. Boyer JN, Kelble CR, Ortner PB, Rudnick DT (2009) Phytoplankton bloom status: Chlorophyll a biomass as an indicator of water quality condition in the southern estuaries of Florida. USA Ecological indicators 9(6):S56-S67

6. Boyle TP, Smillie GM, Anderson JC, Beeson DR (1990) A sensitivity analysis of nine diversity and seven similarity indices. Research Journal of the Water Pollution Control Federation, 749-762

7. Cloern JE, Foster SQ, Kleckner AE (2014) Phytoplankton primary production in the world's estuarinecoastal ecosystems. Biogeosciences 11(9):2477

8. Creel L (2003) Ripple effects: population and coastal regions. Population Reference Bureau, Washington, DC, pp 1-7

9. Desikachary TV (1987) Diatoms from the Bay of Bengal. Atlas of diatoms 3:222-400A

10. Devlin M, Best M, Coates D, Bresnan E, O'Boyle S, Park R, ... Skeats J (2007) Establishing boundary classes for the classification of UK marine waters using phytoplankton communities. Mar Pollut Bull 55(1-6):91-103

11. Digby PGN, Kempton RA (1987) Multivariate Analysis of Ecological Communities. Chapman and Hall, London 
12. Domingues RB, Barbosa A, Galvão H (2008) Constraints on the use of phytoplankton as a biological quality element within the Water Framework Directive in Portuguese waters. Mar Pollut Bull 56(8):1389-1395

13. Grasshoff K, Ehrhardt M, Kremling K (1983) Methods of Seawater Analysis. Second revised and extended. Weinheim' Verlag Chemie

14. Hardikar R, Haridevi CK, Chowdhury M, Shinde N, Ram A, Rokade MA, Rakesh PS (2017) Seasonal distribution of phytoplankton and its association with physico-chemical parameters in coastal waters of Malvan, west coast of India. Environ Monit Assess 189(4):151

15. Herrera-Silveira JA, Morales-Ojeda SM (2009) Evaluation of the health status of a coastal ecosystem in southeast Mexico: Assessment of water quality, phytoplankton and submerged aquatic vegetation. Mar Pollut Bull 59(1-3):72-86

16. Heumann BW, Hackett RA, Monfils AK (2015) Testing the spectral diversity hypothesis using spectroscopy data in a simulated wetland community. Ecological Informatics 25:29-34

17. Houde ED, Rutherford ES (1993) Recent trends in estuarine fisheries: predictions of fish production and yield. Estuaries 16(2):161-176

18. Jha SK, Chavan SB, Pandit GG, Negi BS, Sadasivan S (2002) Behaviour and fluxes of trace and toxic elements in creek sediment near Mumbai, India. Environ Monit Assess 76(2):249-262

19. Thomas J, Velamala SN, Prasad KVSR (2019) Numerical Simulation of Tidal Constituents in Thane Creek and the Ulhas Estuary, West Coast of India. J Coastal Res 35(2):376-388

20. Karydis M, Tsirtsis G (1996) Ecological indices: a biometric approach for assessing eutrophication levels in the marine environment. Sci Total Environ 186(3):209-219

21. Lacouture RV, Johnson JM, Buchanan C, Marshall HG (2006) Phytoplankton index of biotic integrity for Chesapeake Bay and its tidal tributaries. Estuaries Coasts 29(4):598-616

22. Lugoli F, Garmendia M, Lehtinen S, Kauppila P, Moncheva S, Revilla M, ... Basset A (2012) Application of a new multi-metric phytoplankton index to the assessment of ecological status in marine and transitional waters. Ecol Ind 23:338-355

23. Menhinick EF (1964) A comparison of some species-individuals diversity indices applied to samples of field insects. Ecology 45(4):859-861

24. Moser GAO, Ciotti AM, Giannini MFC, Tonini RT, Harari J (2012) Changes in phytoplankton composition in response to tides, wind-induced mixing conditions, and freshwater outflows in an urbanized estuarine complex. Brazilian Journal of Biology 72(1):97-111

25. Naidu VS, Sarma RV (2001) Numerical modeling of tide-induced currents in Thane Creek, west coast of India. Journal of waterway port coastal ocean engineering 127(4):241-244

26. NIO (2009) Monitoring of Coastal Marine and Estuarine Ecology of Maharashtra - Phase I

27. Part A: (Main Report)

28. Ni Longphuirt S, McDermott G, O'Boyle S, Wilkes R, Stengel DB (2019) Decoupling abundance and biomass of phytoplankton communities under different environmental controls: a new multi-metric 
Index. Frontiers in Marine Science 6:312

29. Ninčević-Gladan Ž, Bužančić M, Kušpilić G, Grbec B, Matijević S, Skejić S, ... Morović M (2015) The response of phytoplankton community to anthropogenic pressure gradient in the coastal waters of the eastern Adriatic Sea. Ecol Ind 56:106-115

30. Nixon SW (1995) Coastal marine eutrophication: a definition, social causes, and future concerns. Ophelia 41(1):199-219

31. Parsons TR, Maita Y, Lalli CM (1984) A Manual of Chemical and Biological Methods for Seawater Analysis. Pergamon Press, Oxford, p 173

32. Revilla M, Franco J, Bald J, Borja Á, Laza A, Seoane S, Valencia V (2009) Assessment of the phytoplankton ecological status in the Basque coast (northern Spain) according to the European Water Framework Directive. J Sea Res 61(1-2):60-67

33. Sasamal SK, Rao KH, Suryavansi UM (2007) Sewage and industrial pollution in and around Thane Creek, Mumbai using high resolution IRS data. Int J Remote Sens 28(19):4391-4395

34. Shannon CE, Weaver W (1949) The mathematical theory of communication. University of Illinois Press, Urbana, $117 \mathrm{p}$

35. Sheldon AL (1969) Equitability indices: dependence on the species count. Ecology 50(3):466-467

36. Simboura N, Panayotidis P, Papathanassiou E (2005) A synthesis of the biological quality elements for the implementation of the European Water Framework Directive in the Mediterranean ecoregion: the case of Saronikos Gulf. Ecological indicators 5(3):253-266

37. Singare PU, Lokhande RS, Pathak PP (2010) Study on physico-chemical properties and heavy metal content of the soil samples from Thane Creek of Maharashtra, India. Interdisciplinary Environmental Review 11(1):38-56

38. Singare PU, Bhattacharjee SS, Lokhande RS (2013) Analysis of the heavy metal pollutants in sediment samples collected from Thane Creek of Maharashtra, India. International Journal of Sustainable Society 5(3):296-308

39. Sivadas SK, Nagesh R, Gupta GVM, Gaonkar U, Mukherjee I, Ramteke D, Ingole BS (2016) Testing the efficiency of temperate benthic biotic indices in assessing the ecological status of a tropical ecosystem. Mar Pollut Bull 106(1-2):62-76

40. Spatharis S, Tsirtsis G (2010) Ecological quality scales based on phytoplankton for the implementation of Water Framework Directive in the Eastern Mediterranean. Ecol Ind 10(4):840-847

41. Spatharis S, Roelke DL, Dimitrakopoulos PG, Kokkoris GD (2011) Analyzing the (mis) behavior of Shannon index in eutrophication studies using field and simulated phytoplankton assemblages. Ecological indicators 11(2):697-703

42. Subrahmanyan R (1946) A systematic account of the marine plankton diatoms of the Madras coast. In Proceedings of the Indian Academy of Sciences-Section B (Vol. 24, No. 4, pp. 85-197). Springer India 
43. Thillai RK, Rajkumar M, Sun J, Ashok PV, Perumal P (2010) Seasonal variations of phytoplankton diversity in the Coleroon coastal waters, southeast coast of India. Acta Oceanol Sin 29(5):97-108

44. Thomas J, Velamala SN, Prasad KVSR (2019) Numerical Simulation of Tidal Constituents in Thane Creek and the Ulhas Estuary, West Coast of India. J Coastal Res 35(2):376-388

45. Tomas CR (ed) (1997) Identifying marine phytoplankton. Elsevier

46. Vijay R, Khobragade PJ, Dhage SS, Gupta A, Wate SR (2015) Tidal and seasonal variations in water quality of Thane creek, Mumbai, India: a statistical analysis. Indian Journal of Geo-Marine Sciences 44(06):808-817

47. Vijay R, Khobragade PJ, Sohony RA, Kumar R, Wate SR (2014) Hydrodynamic and water quality simulation of Thane creek. an impact of sewage discharges, Mumbai

48. Vincent C, Heinrich H, Edwards A, Nygaard K, Haythornthwaite J (2002) Guidance on typology, reference conditions and classification systems for transitional and coastal waters. CIS working group, 2, 119

49. Winder M, Carstensen J, Galloway AW, Jakobsen HH, Cloern JE (2017) The land-sea interface: A source of high-quality phytoplankton to support secondary production. Limnol Oceanogr 62(S1):S258-S271

50. Wu N, Schmalz B, Fohrer N (2012) Development and testing of a phytoplankton index of biotic integrity (P-IBI) for a German lowland river. Ecol Ind 13(1):158-167

\section{Tables}

Table 1 Details of major wastewater discharge into Thane Creek

\begin{tabular}{|lll|}
\hline Sr. No. & Discharge location & Flow (MLD) \\
\hline 1 & Bhandup $^{\mathrm{a}}$ & 145 \\
\hline 2 & Ghatkopar $^{\mathrm{a}}$ & 195 \\
\hline 3 & Colabaoutfall $^{\mathrm{a}}$ & 37 \\
\hline 4 & Drains on the east and west side of creek & \\
\hline
\end{tabular}

${ }^{a}$ Maharashtra Pollution Control Board

b Vijay et al., 2014

Table 2 Description of the study area along with their primary disturbance sources 


\begin{tabular}{|c|c|c|c|c|}
\hline Station & Study site & $\begin{array}{l}\text { Geographical } \\
\text { coordinates }\end{array}$ & $\begin{array}{l}\text { Depth } \\
\text { (m) }\end{array}$ & Source of disturbance \\
\hline \multirow[t]{2}{*}{ TC1 } & \multirow[t]{2}{*}{ Vashi } & $19^{\circ} 2 ' 45.00^{\prime \prime} \mathrm{N}$ & \multirow[t]{2}{*}{9} & \multirow[t]{2}{*}{ Domestic and industrial waste } \\
\hline & & $72^{\circ} 58^{\prime} 43.00^{\prime \prime} \mathrm{E}$ & & \\
\hline \multirow[t]{2}{*}{ TC2 } & \multirow[t]{2}{*}{ Trombay } & $18^{\circ} 59^{\prime} 53.00^{\prime \prime} \mathrm{N}$ & \multirow[t]{2}{*}{12} & \multirow[t]{2}{*}{ Domestic and industrial waste } \\
\hline & & $72^{\circ} 57^{\prime} 50.00^{\prime \prime} \mathrm{E}$ & & \\
\hline \multirow[t]{2}{*}{ TC3 } & \multirow[t]{2}{*}{ Panvek creek } & $18^{\circ} 59^{\prime} 21.00^{\prime \prime} \mathrm{N}$ & \multirow[t]{2}{*}{11} & \multirow[t]{2}{*}{ Domestic and industrial waste } \\
\hline & & $73^{\circ} 0^{\prime} 20.00^{\prime \prime} \mathrm{E}$ & & \\
\hline \multirow[t]{2}{*}{ TC4 } & \multirow{2}{*}{$\begin{array}{l}\text { Elephanta } \\
\text { caves }\end{array}$} & $18^{\circ} 58^{\prime} 40.51^{\prime \prime} \mathrm{N}$ & \multirow[t]{2}{*}{7} & \multirow{2}{*}{$\begin{array}{l}\text { Transportation, Domestic and } \\
\text { industrial waste }\end{array}$} \\
\hline & & $72^{\circ} 56^{\prime} 43.22^{\prime \prime} \mathrm{E}$ & & \\
\hline \multirow[t]{2}{*}{ TC5 } & \multirow{2}{*}{$\begin{array}{l}\text { Jawahar } \\
\text { Dweep }\end{array}$} & $18^{\circ} 58^{\prime} 5.00^{\prime \prime} \mathrm{N}$ & \multirow[t]{2}{*}{7} & \multirow{2}{*}{$\begin{array}{l}\text { Transportation and fishing activities, } \\
\text { Dredging }\end{array}$} \\
\hline & & $72^{\circ} 53^{\prime} 10.00^{\prime \prime} \mathrm{E}$ & & \\
\hline \multirow[t]{2}{*}{ TC6 } & \multirow[t]{2}{*}{ Mora } & $18^{\circ} 55^{\prime} 22.00^{\prime \prime} \mathrm{N}$ & \multirow[t]{2}{*}{12} & \multirow[t]{2}{*}{ Domestic waste and fishing activity } \\
\hline & & $72^{\circ} 53^{\prime} 58.00^{\prime \prime} \mathrm{E}$ & & \\
\hline \multirow[t]{2}{*}{ TC7 } & \multirow[t]{2}{*}{ Fort } & $18^{\circ} 54^{\prime} 3.16^{\prime \prime} \mathrm{N}$ & \multirow[t]{2}{*}{12} & \multirow{2}{*}{$\begin{array}{l}\text { Harbour, transportation and fishing } \\
\text { activities }\end{array}$} \\
\hline & & $72^{\circ} 52^{\prime} 23.11^{\prime \prime} \mathrm{E}$ & & \\
\hline \multirow[t]{2}{*}{ TC8 } & \multirow[t]{2}{*}{ Bori } & $18^{\circ} 51^{\prime} 50.00^{\prime \prime} \mathrm{N}$ & \multirow[t]{2}{*}{9} & \multirow{2}{*}{$\begin{array}{l}\text { Domestic, recreational and fishing } \\
\text { activities }\end{array}$} \\
\hline & & $72^{\circ} 53^{\prime} 49.00^{\prime \prime} \mathrm{E}$ & & \\
\hline TC9 & Dharamtar & $18^{\circ} 49^{\prime} 58.98^{\prime \prime} \mathrm{N}$ & 13 & Industrial and domestic waste \\
\hline & & $72^{\circ} 56^{\prime} 39.48^{\prime \prime} \mathrm{E}$ & & \\
\hline TC10 & Colaba & $18^{\circ} 52^{\prime} 48.00^{\prime \prime} \mathrm{N}$ & 14 & Industrial and domestic waste, \\
\hline & & $72^{\circ} 48^{\prime} 59.00^{\prime \prime} \mathrm{E}$ & & \\
\hline TC11 & Mumbai & $18^{\circ} 51^{\prime} 26.62^{\prime \prime} \mathrm{N}$ & 15 & Industrial and domestic waste, \\
\hline & & $72^{\circ} 50^{\prime} 10.10^{\prime \prime} \mathrm{E}$ & & \\
\hline TC12 & Revas & $18^{\circ} 48^{\prime} 59.00^{\prime \prime} \mathrm{N}$ & 14 & recreational, Industrial and domestic \\
\hline & & $72^{\circ} 52^{\prime} 11.00^{\prime \prime} \mathrm{E}$ & & \\
\hline TC13 & Colaba & $18^{\circ} 54^{\prime} 4.00^{\prime \prime} \mathrm{N}$ & 19 & Minimum anthropogenic activities \\
\hline & & $72^{\circ} 46^{\prime} 16.00^{\prime \prime} \mathrm{E}$ & & \\
\hline TC14 & Mumbai & $18^{\circ} 49^{\prime} 37.00^{\prime \prime} \mathrm{N}$ & 17 & Harbour/transportation activities \\
\hline & & $72^{\circ} 47^{\prime} 34.00^{\prime \prime} \mathrm{E}$ & & \\
\hline
\end{tabular}




\begin{tabular}{|c|c|c|c|c|}
\hline \multirow[t]{2}{*}{ TC15 } & \multirow[t]{2}{*}{ Sasavane } & $18^{\circ} 47^{\prime} 20.00^{\prime \prime} \mathrm{N}$ & \multirow[t]{2}{*}{18} & \multirow[t]{2}{*}{ recreational and domestic waste } \\
\hline & & $72^{\circ} 49^{\prime} 37.00^{\prime \prime} \mathrm{E}$ & & \\
\hline \multirow[t]{2}{*}{ TC16 } & \multirow[t]{2}{*}{ Off-shore } & $18^{\circ} 53^{\prime} 52.00^{\prime \prime} \mathrm{N}$ & \multirow[t]{2}{*}{24} & \multirow[t]{2}{*}{ Minimum anthropogenic activities } \\
\hline & & $72^{\circ} 35^{\prime} 44.00^{\prime \prime} \mathrm{E}$ & & \\
\hline
\end{tabular}

Table 3 Thresholds used for each index. Superscript letters indicate the references for each index (see footnote)

\begin{tabular}{|llllll|}
\hline \multirow{2}{*}{ Index } & \multicolumn{2}{l}{ Classification } & & \\
& High & Good & Moderate & Poor & Bad \\
\hline Chl $a\left(\mu \mathrm{g} \mathrm{I}^{-1}\right)^{\mathrm{a}}$ & $<2$ & $2-5$ & $6-10$ & $11-15$ & $>15$ \\
\hline $\begin{array}{l}\text { Abundance (Cells } \\
\left.\mathrm{I}^{-1}\right)^{\mathrm{b}}\end{array}$ & - & $<129000$ & $\begin{array}{l}129000- \\
349000\end{array}$ & $>349000$ & - \\
\hline $\mathrm{H}^{\mathrm{c}, \mathrm{d}}$ & $>4.0$ & $3-4$ & $2-3$ & $1-2$ & $\leq 1.0$ \\
\hline $\mathrm{MDI}^{\mathrm{b}}$ & $>0.15$ & $0.15-0.09$ & $0.09-0.05$ & $0.05-0.03$ & $0.03-0.01$ \\
\hline $\mathrm{IPI}^{\mathrm{b}}$ & $\mathrm{IPI}>0.9$ & $0.9>\mathrm{IPI} \geq 0.72$ & $0.72>\mathrm{IPI} \geq 0.53$ & $0.53>\mathrm{IPI} \geq 0.0$ & 0 \\
\hline $\mathrm{MMPI}^{\mathrm{e}}$ & $\mathrm{MMPI} \geq 0.8$ & $0.8>\mathrm{MMPI} \geq 0.6$ & $0.6>\mathrm{MMPI} \geq 0.4$ & $0.4>\mathrm{MMPI} \geq 0.2$ & $\mathrm{MMPI}<0.2$ \\
\hline
\end{tabular}

a Borja et al., 2004

${ }^{\mathrm{b}}$ Herrera-Silveira \& Morales-Ojeda, 2009

${ }^{c}$ Labrune et al., 2006

d Hardikar et al., 2017

e Longphuirt et al., 2019

Table 4 Ecological quality status derived from six phytoplankton community indices with their values in parentheses for the area sampled 


\begin{tabular}{|c|c|c|c|c|c|c|}
\hline Stations & Chl a & Abundance & MDI & $\mathrm{H}^{\prime}$ & IPI & MMPI \\
\hline \multirow[t]{2}{*}{ TC1 } & Moderate & Moderate & Moderate & Good & Good & Good \\
\hline & $(5.40)$ & $(151300)$ & $(0.07)$ & $(3.68)$ & $(0.73)$ & $(0.64)$ \\
\hline \multirow[t]{2}{*}{ TC2 } & Moderate & Moderate & Moderate & Good & Poor & Good \\
\hline & $(8.95)$ & $(166600)$ & $(0.05)$ & $(3.43)$ & $(0.49)$ & $(0.61)$ \\
\hline \multirow[t]{2}{*}{ TC3 } & Poor & Poor & Moderate & Good & Poor & Poor \\
\hline & (11.16) & (511300) & $(0.05)$ & $(3.70)$ & $(0.28)$ & $(0.32)$ \\
\hline \multirow[t]{2}{*}{ TC4 } & Moderate & Poor & Moderate & Moderate & Poor & Poor \\
\hline & $(6.57)$ & (345800) & $(0.05)$ & $(2.88)$ & $(0.35)$ & $(0.31)$ \\
\hline \multirow[t]{2}{*}{ TC5 } & Moderate & Poor & Poor & Moderate & Poor & Poor \\
\hline & $(6.03)$ & $(620000)$ & $(0.04)$ & $(2.89)$ & $(0.28)$ & $(0.22)$ \\
\hline \multirow[t]{2}{*}{ TC6 } & Moderate & Poor & Poor & Moderate & Poor & Poor \\
\hline & $(6.82)$ & $(640300)$ & $(0.04)$ & $(2.75)$ & $(0.25)$ & $(0.20)$ \\
\hline \multirow[t]{2}{*}{ TC7 } & Moderate & Poor & Poor & Moderate & Poor & Bad \\
\hline & $(5.48)$ & (895900) & $(0.04)$ & $(2.45)$ & $(0.24)$ & $(0.17)$ \\
\hline \multirow[t]{2}{*}{ TC8 } & Poor & Poor & Bad & Moderate & Poor & Bad \\
\hline & $(14.91)$ & (3389100) & $(0.02)$ & $(2.48)$ & $(0.05)$ & $(0.06)$ \\
\hline \multirow[t]{2}{*}{ TC9 } & Bad & Poor & Bad & Moderate & Bad & Bad \\
\hline & (16.78) & $(6864900)$ & $(0.02)$ & $(2.31)$ & $(0.00)$ & $(0.04)$ \\
\hline \multirow[t]{2}{*}{ TC10 } & Moderate & Poor & Bad & Bad & Poor & Bad \\
\hline & $(6.89)$ & $(4348400)$ & $(0.02)$ & $(0.93)$ & $(0.05)$ & $(0.06)$ \\
\hline \multirow[t]{2}{*}{ TC11 } & Moderate & Poor & Bad & Bad & Poor & Bad \\
\hline & $(5.25)$ & (3487600) & $(0.02)$ & $(0.98)$ & $(0.09)$ & $(0.09)$ \\
\hline \multirow[t]{2}{*}{ TC12 } & Moderate & Poor & Poor & Moderate & Poor & Bad \\
\hline & $(5.11)$ & (1119800) & $(0.04)$ & $(2.44)$ & $(0.23)$ & $(0.16)$ \\
\hline \multirow[t]{2}{*}{ TC13 } & High & Moderate & Moderate & Good & Good & Good \\
\hline & $(1.56)$ & (176400) & $(0.07)$ & (3.39) & $(0.90)$ & $(0.76)$ \\
\hline \multirow[t]{2}{*}{ TC14 } & High & Poor & Moderate & Moderate & Moderate & Good \\
\hline & $(1.40)$ & (239500) & $(0.05)$ & $(2.66)$ & $(0.71)$ & $(0.65)$ \\
\hline
\end{tabular}




\begin{tabular}{|lllllll|} 
TC15 & Good & Poor & Moderate & Moderate & Moderate & Moderate \\
& $(2.17)$ & $(240700)$ & $(0.06)$ & $(2.91)$ & $(0.68)$ & $(0.52)$ \\
TC16 & High & Good & Good & Good & High & High \\
& $(0.97)$ & $(64600)$ & $(0.11)$ & $(3.06)$ & $(1.00)$ & $(1.00)$ \\
\hline
\end{tabular}

Table 5 Criteris used for measurement of agreement/disagreement between indices for each station. Full agreement was measured as [a]+[g], partial as [b]+[f] and disagreement as [c]+[d]+[e] (Blanchet et al., 2008)

\begin{tabular}{|lll|}
\hline Sum of the score & Interpretation & \\
\hline 0 & Full agreement of the six biotic indices on moderate or worse & [a] \\
\hline & EcoQ status ('not acceptable') & \\
\hline 1 & Partial agreement (five out of six) on moderate or worse & [b] \\
\hline & EcoQ status ('not acceptable') & [c] \\
\hline 2 & A disagreement between the six indices & [d] \\
\hline 4 & A disagreement between the six indices & [e] \\
\hline 5 & A disagreement between the six indices & [f] \\
\hline & Partial agreement (five out of six) on good or higher & [g] \\
\hline 6 & EcoQ status ('acceptable') & \\
\hline
\end{tabular}

Table 6 Spearman's rank correlation between six indices

\begin{tabular}{|c|c|c|c|c|c|}
\hline & $\mathrm{Chl} a$ & Abundance & MDI & $\mathrm{H}$ & IPI \\
\hline Abundance & .429 & & & & \\
\hline MDI & -.497 & $-.937^{\star \star}$ & & & \\
\hline $\mathrm{H}^{\prime}$ & -.093 & $-.861^{\star \star}$ & $.853^{\star \star}$ & & \\
\hline IPI & $-.661^{\star *}$ & $-.926^{\star \star}$ & $.936^{* *}$ & $.729^{\star \star}$ & \\
\hline MMPI & $-.565^{*}$ & $-.961^{\star *}$ & $.935^{\star *}$ & $.805^{\star \star}$ & $.970^{\star *}$ \\
\hline
\end{tabular}

** $p<0.01$ 
$* p<0.05$

Table 7 Depth averaged values of physico-chemical parameters at different stations of Thane creek during April 20

\begin{tabular}{|llllllll|}
\hline Stations & WT & Salinity & $\mathrm{pH}$ & $\mathrm{DO}$ & $\begin{array}{l}\text { Phosphate }\left(\mu \mathrm{M} \mathrm{I}^{-}\right. \\
\left(\mathrm{mg} \mathrm{I}^{-}\right.\end{array}$ & $\begin{array}{l}\text { DIN }\left(\mu \mathrm{M} \mathrm{I}^{-}\right. \\
1)\end{array}$ & $\begin{array}{l}\text { silicate }\left(\mu \mathrm{M} \mathrm{I}^{-}\right. \\
1)\end{array}$ \\
\hline TC1 & & & & & & \\
\hline TC2 & 32.25 & 33.83 & 7.74 & 3.47 & 5.98 & 24.29 & 27.64 \\
\hline TC3 & 32.25 & 33.10 & 7.80 & 3.09 & 6.66 & 29.86 & 30.14 \\
\hline TC4 & 31.00 & 34.83 & 8.00 & 4.61 & 5.60 & 40.40 & 23.84 \\
\hline TC5 & 31.50 & 35.00 & 7.85 & 5.39 & 3.30 & 24.53 & 18.84 \\
\hline TC6 & 30.88 & 35.12 & 7.93 & 5.82 & 1.96 & 31.55 & 19.79 \\
\hline TC7 & 29.25 & 35.60 & 8.07 & 6.57 & 0.48 & 25.66 & 18.91 \\
\hline TC8 & 30.63 & 35.30 & 8.03 & 6.42 & 1.40 & 5.72 & 3.89 \\
\hline TC9 & 31.50 & 35.28 & 8.11 & 6.97 & 0.96 & 15.27 & 10.00 \\
\hline TC10 & 28.88 & 35.57 & 8.04 & 6.18 & 0.51 & 8.63 & 5.31 \\
\hline TC11 & 29.75 & 35.56 & 8.03 & 6.02 & 0.74 & 6.04 & 4.48 \\
\hline TC12 & 30.25 & 35.53 & 7.86 & 7.03 & 1.28 & 20.84 & 4.38 \\
\hline TC13 & 30.25 & 35.64 & 7.96 & 5.58 & 4.61 & 7.97 & 9.14 \\
\hline TC14 & 30.75 & 35.61 & 7.98 & 6.38 & 6.90 & 9.16 & 7.09 \\
\hline TC15 & 30.75 & 35.45 & 8.00 & 6.55 & 1.57 & 7.31 & 6.58 \\
\hline TC16 & 30.63 & 35.70 & 7.96 & 6.38 & 2.80 & 10.57 & 10.78 \\
\hline
\end{tabular}

Figures 


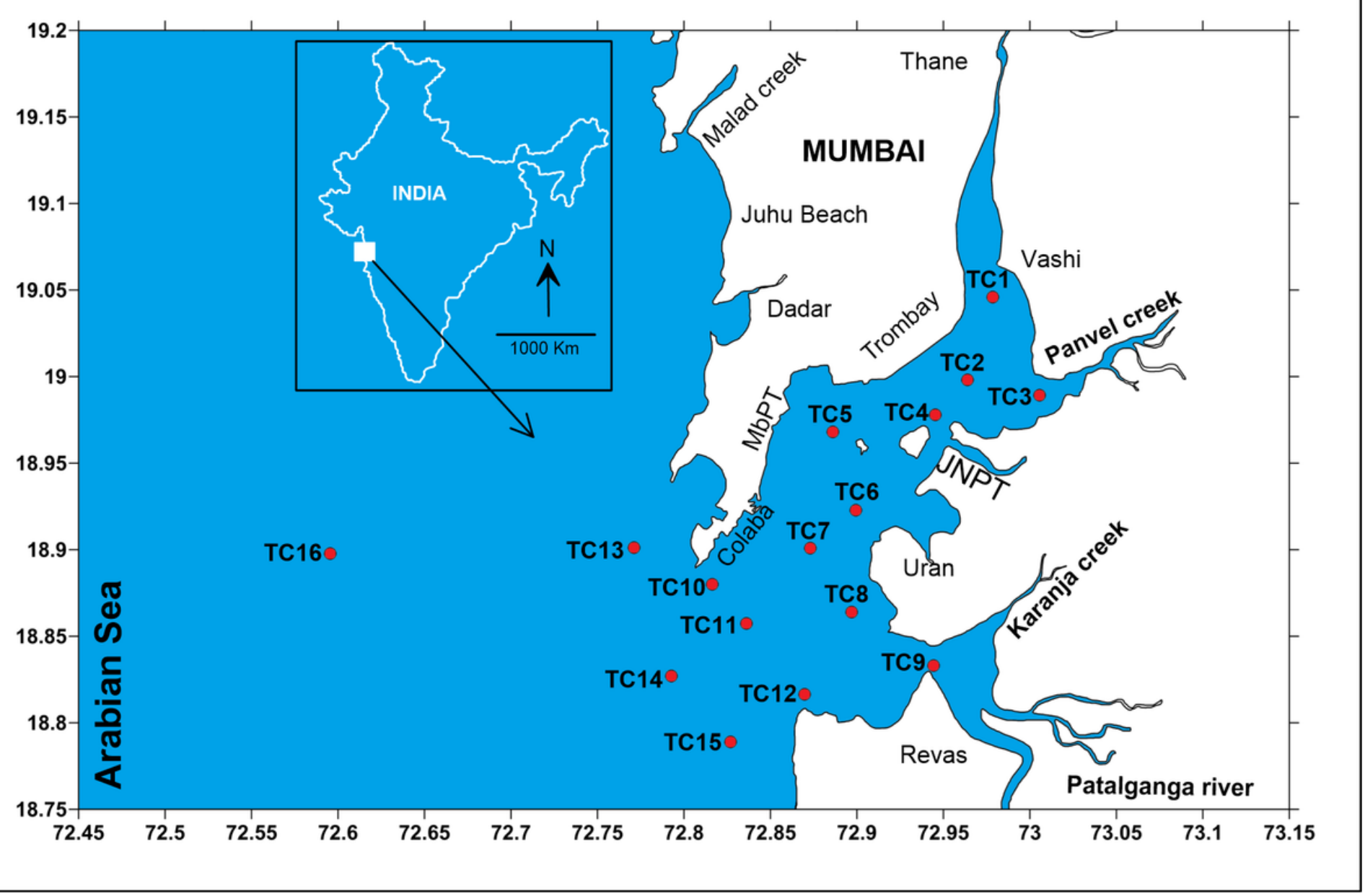

\section{Figure 1}

Map of study area (Thane Creek) showing position of sampling locations and reference site Note: The designations employed and the presentation of the material on this map do not imply the expression of any opinion whatsoever on the part of Research Square concerning the legal status of any country, territory, city or area or of its authorities, or concerning the delimitation of its frontiers or boundaries. This map has been provided by the authors. 


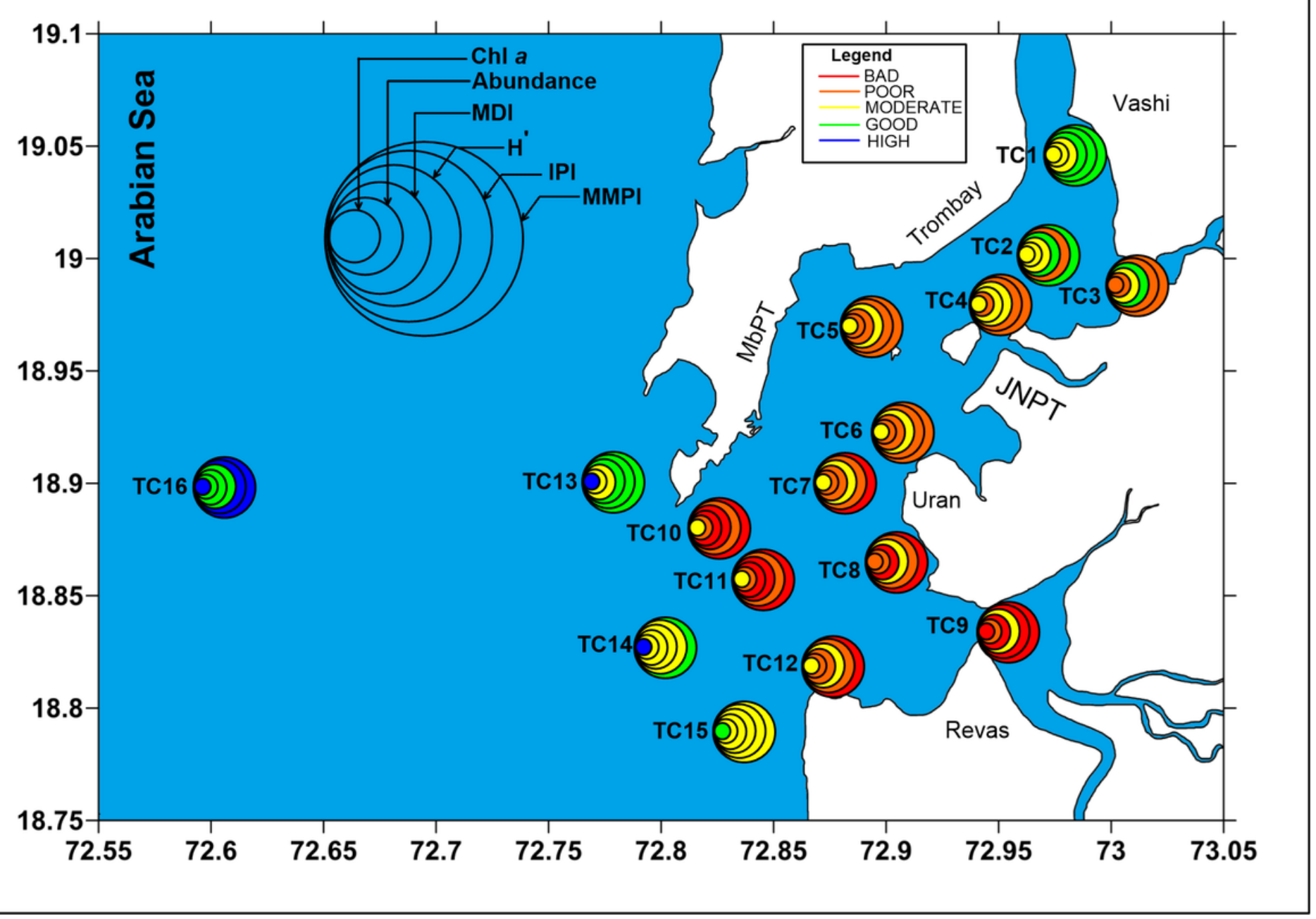

\section{Figure 2}

Graphical representation of EcoQS assign by six phytoplankton indices to each station Note: The designations employed and the presentation of the material on this map do not imply the expression of any opinion whatsoever on the part of Research Square concerning the legal status of any country, territory, city or area or of its authorities, or concerning the delimitation of its frontiers or boundaries. This map has been provided by the authors. 


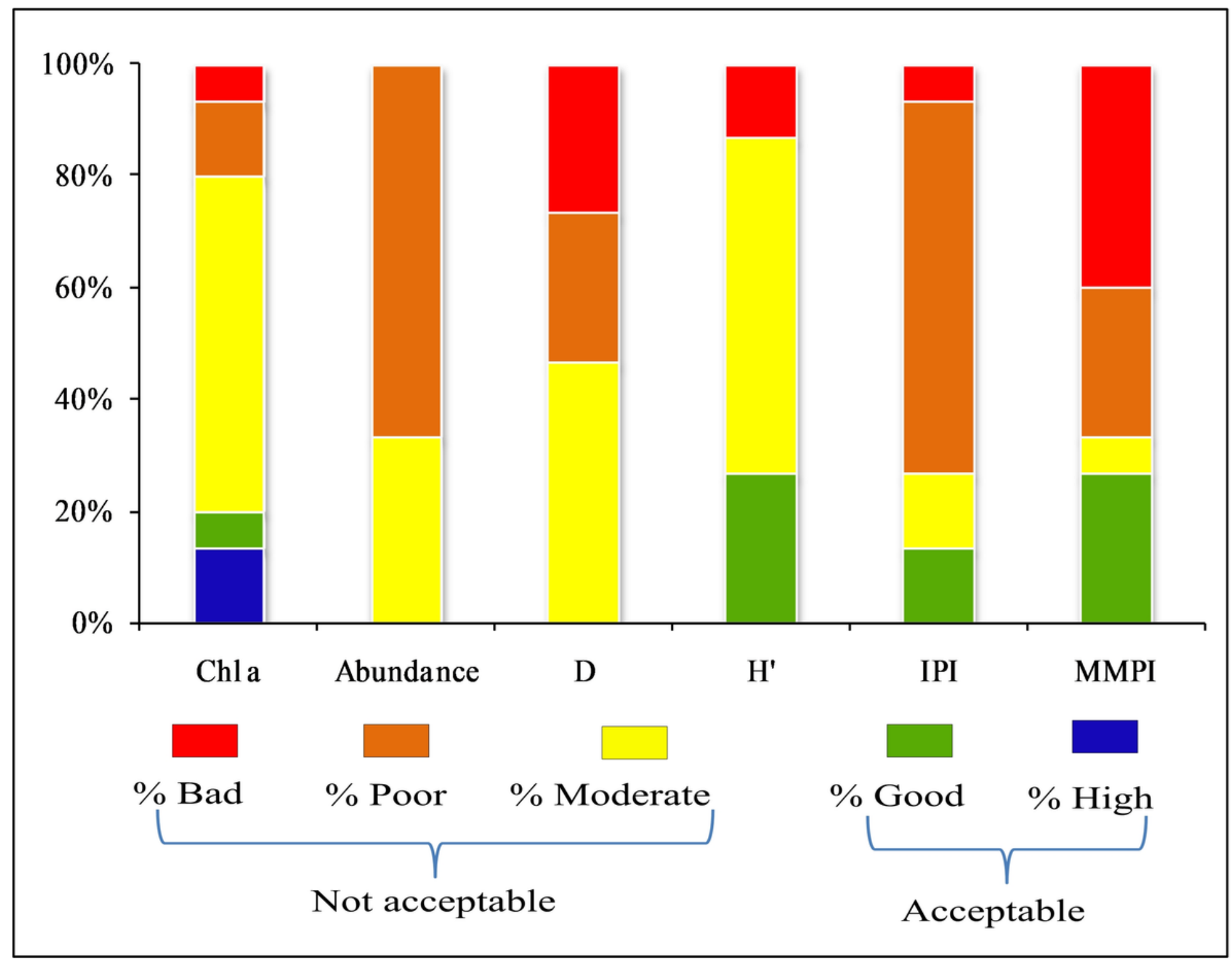

Figure 3

Integrated EcoQS of Thane Creek using six phytoplankton indices 


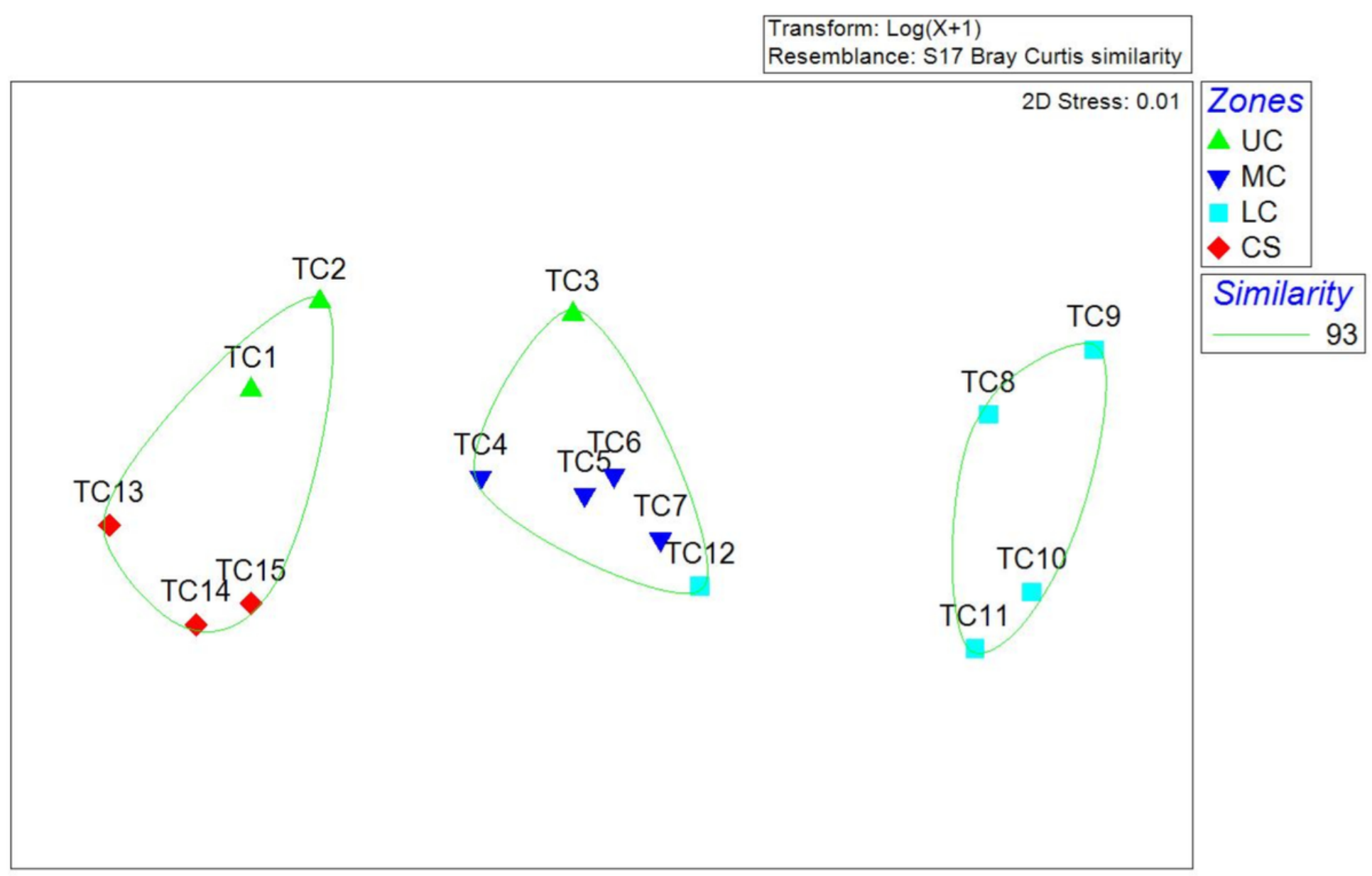

Figure 4

Multidimensional scaling (nMDS) plot of phytoplankton indices data at all sampling stations in Thane Creek 